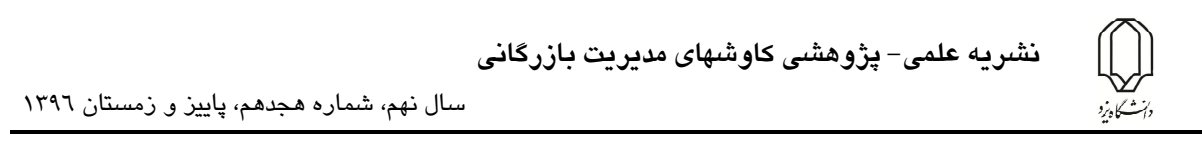

حكرانى و صادرات مبتنى بر فناورى برتر:

مطالعه موردى كشورهاى عضو

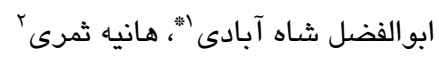

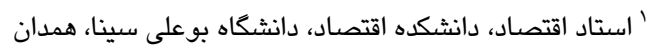

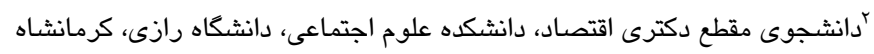

تاريخ بذيرش:

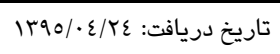

\title{
جִكيده
}

در عصرحاضر، بكاركيرى بيش از يِيش كاربردهاى جديدى از علم ودانش روز در توليدات داخلى و كَسترش مرزهاى فناورى و افزايش ضريب نفوذ آن در راهبردهاى توسعه صادرات، نظريات اقتصادى را به سوى عوامل موثر بر صادرات مبتنى بر فناورى برتر كه در

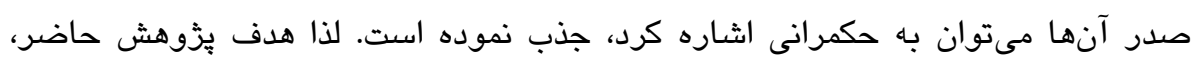
بررسى تاثير حكمرانى بر صادرات مبتنى بر فناورى برتر كثورهاى درحال توسعه عضو جو

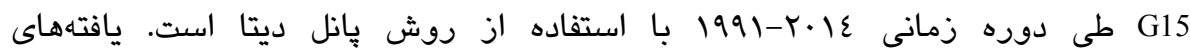
اقتصادسنجى مطالعه، ارتباط مثبت و معنادار شاخصهاى حكمرانى و ديكر متغيرهاى

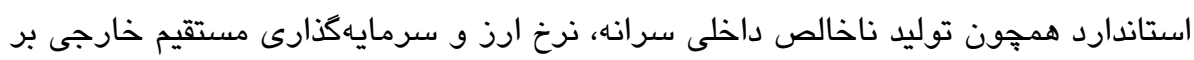
صادرات مبتنى بر فناورى برتر را تأييد مىكند. در واقع، ارتقا در هر يك از ابعاد حكمرانى (از طريق مشاركت مردم و ثبات سياسى، اثربخشى دولت و سياستكذارى مبتنى بر شناخت، حمايت از حقوق مالكيت مادى و فكرى، تنظيم كرى مقررات، آزادى بيان و كنترل فساد) بر صادرات با فناورى برتر از نظر آمارى اثر مثبت و معنادارى دئ دارد.

كلمات كليدى: حكمرانى، صادرات مبتنى بر فناورى برتر، پِانل ديتا، G15

Email: shahabadia@gmail.com : نويسنده مسئول - 
مقدمه

يكى از علل رشد اقتصادى جشمكير طى دو دهـ كذشته در سراسر جهان، كسترش ته

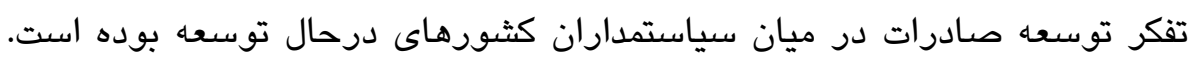

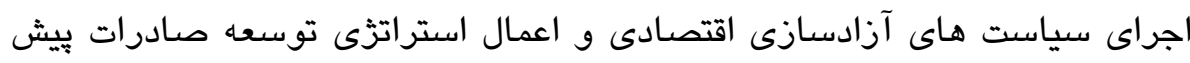

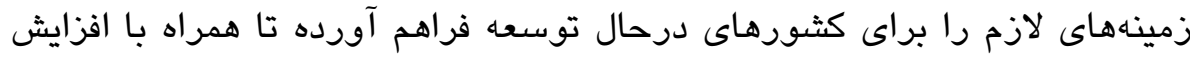

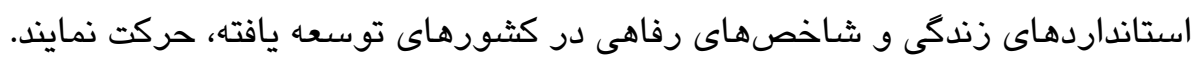

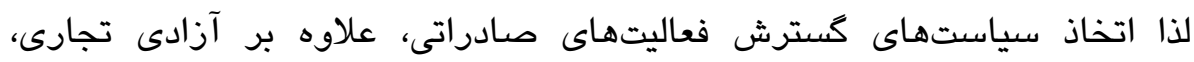

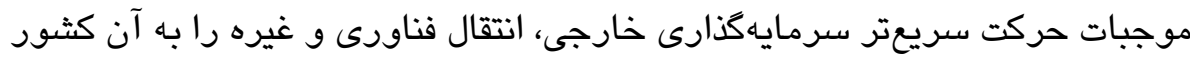

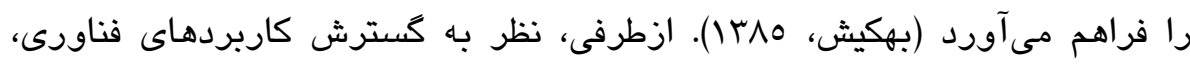

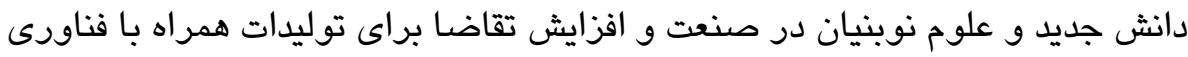

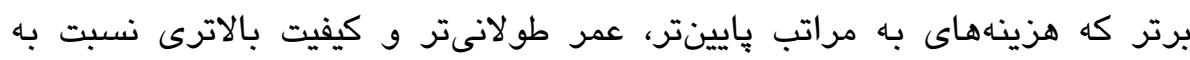

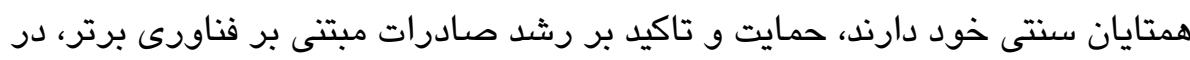
اولويت سياستكذارىهاى كلان اقتصادى بهويزه در كشورهاى درحال توسعه قرار

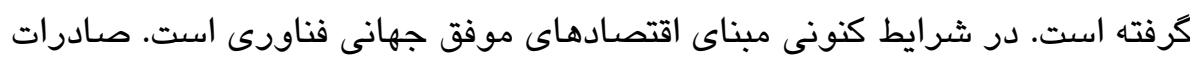

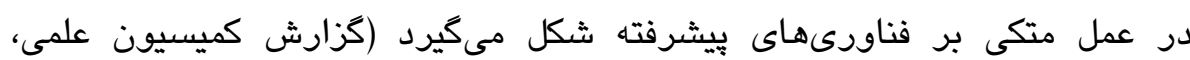

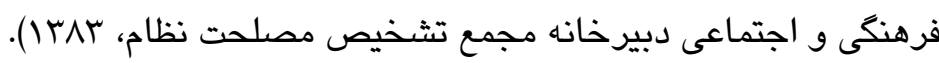

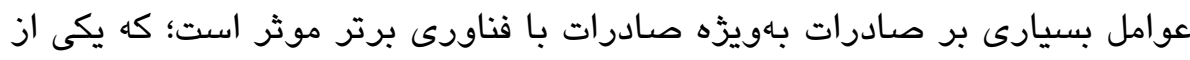

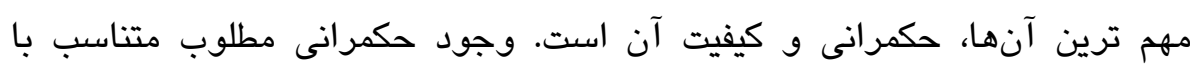

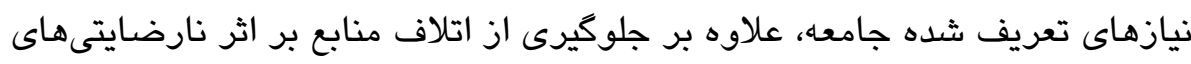

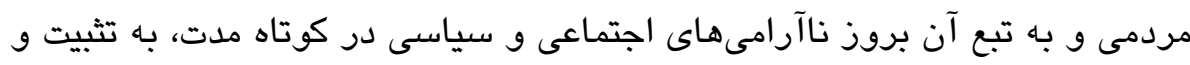

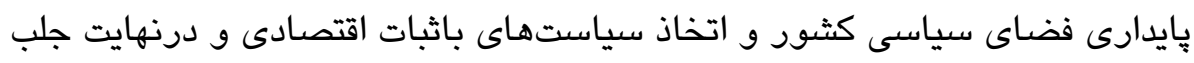

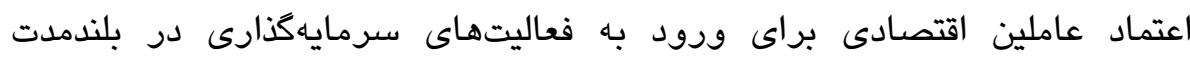

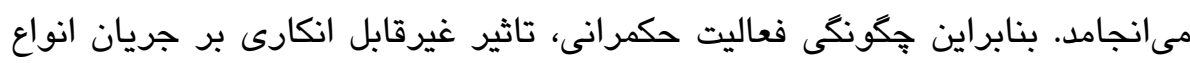

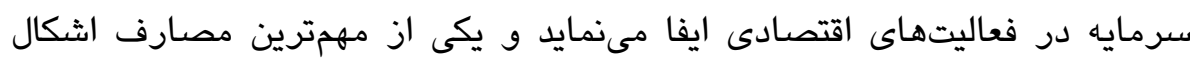

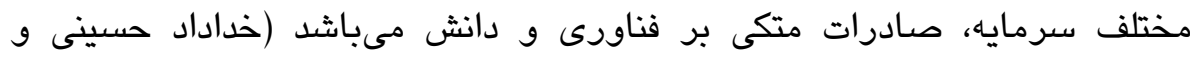

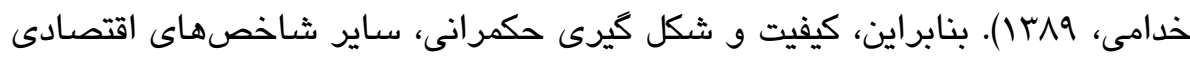

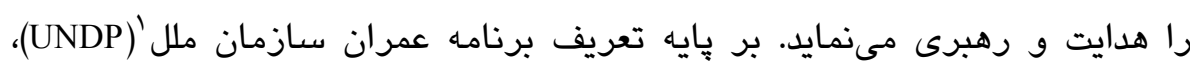

1- United Nations Development Program 
شاخصهاى حكمانى خوب به مديريت امور عمومى بر اساس حاكميت قانون،

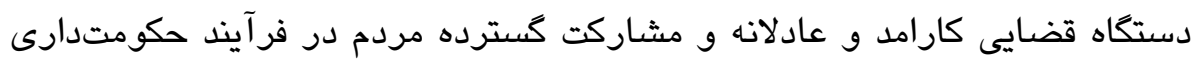

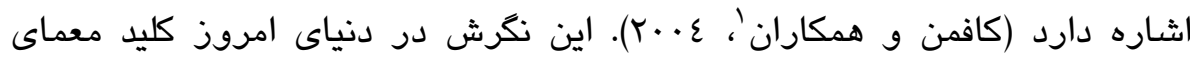

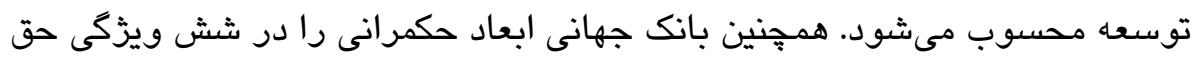
اظهارنظر (شفافيت) و پِاسخكويى، پِايدارى سياسى، كارايى و اثربخشى دولى دولت، كيفيت

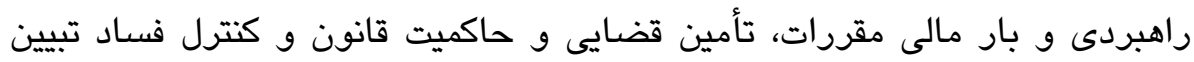

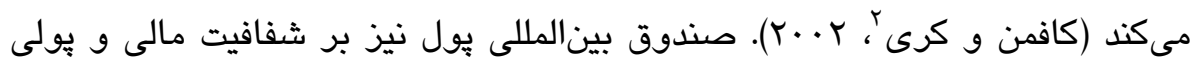

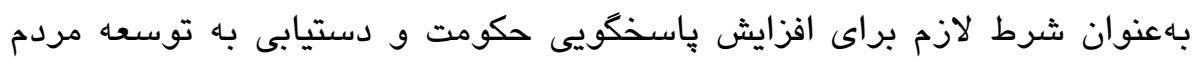

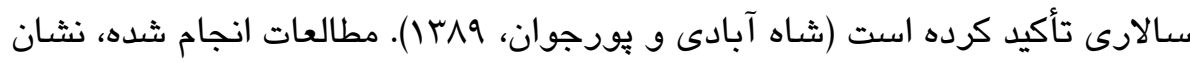

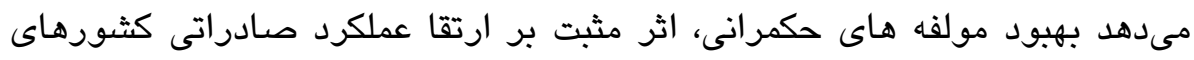

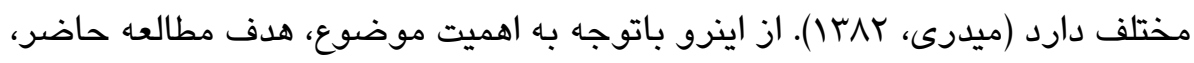

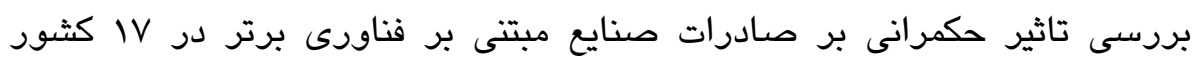

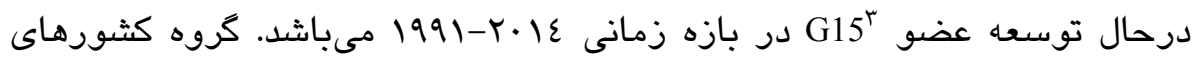

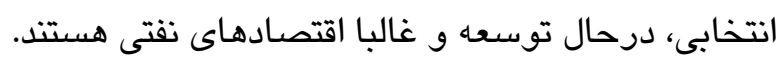
ادامه ساختار مقاله بدينترتيب است كه: در بخش دوم مطالعات مختلف نظرى ونى و

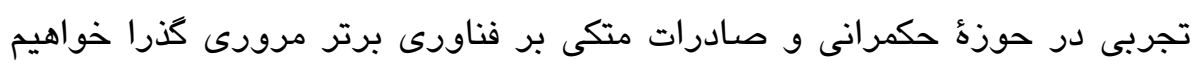

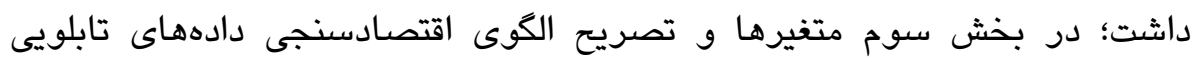

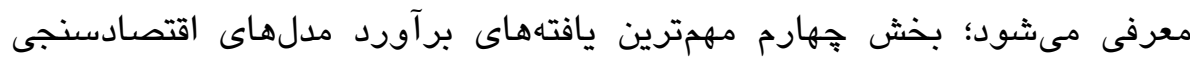

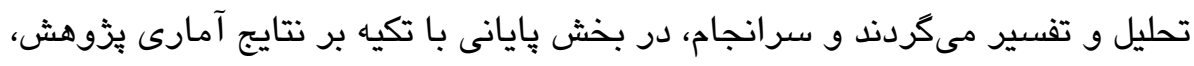
نتيجه كيرى و يِيشنهادات ارائه مىشيود.

\section{ادبيات موضوع}

حكمرانى خوبُ مفهومى است كه از سالهاى ميانى دهـه .9 ميلادى، با كَترش

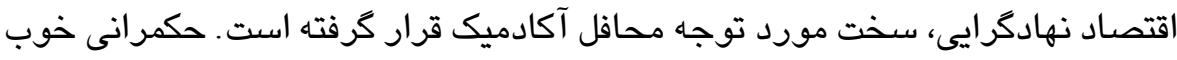
به معناى سازوكارها، فر آيندها و نهادهايى است كه به وته واسطه آن، شهروندان، كرودها

1- Kaufmann

2- Kaufmann and Kraay

r- الجزاير، مصر، كنيا، نيجريه، سنكال، زيمباوه، هند، اندونزى، مالزى، سريلانكا، آرزانتين، برزيل، 4 - Good Governance

شيلى، جامائيكا، مكزيك، ونزوئلا و جمهورى اسلامى ايران. 
و نهادهاى مدنى منافع خود را دنبال مىكنتد و حقوق قانونى خود را به اجرا مىكذارند. به تعبيرى ديكر، حكمرانى خوب شامل ايجاد حمايت و اجراى حقوق مالكيت، بدون محدود شدن مبادلات بازار است. شاخصهاى حكمرانى خوب شامل پاسخكويى، ثبات سياسى، اثربخشى دولت، حاكميت قانون، كيفيت قانونكذارى و كنترل فساد هستند. هر

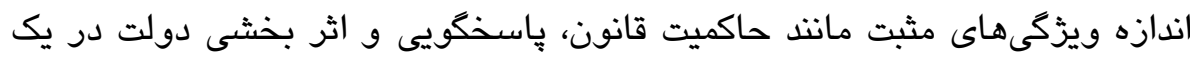
جامعه بيشتر و در سوى ديكر، فساد و بى ثباتى سياسى كمتر باشند، حكمرانى براى

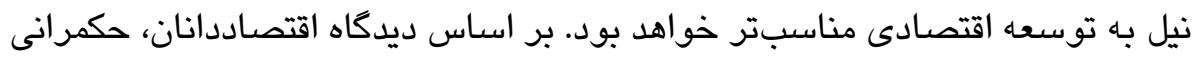

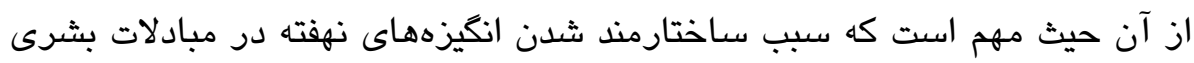

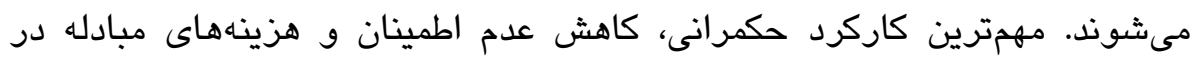

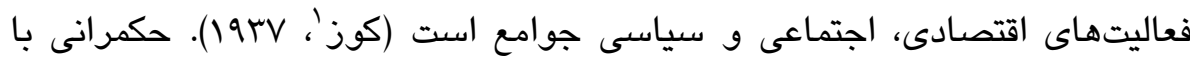

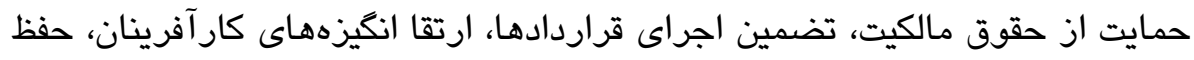
ثبات در سطح كلان اقتصادى، مديريت ريسك يذيرى و خطرجويى واسطهاهاى مالى،

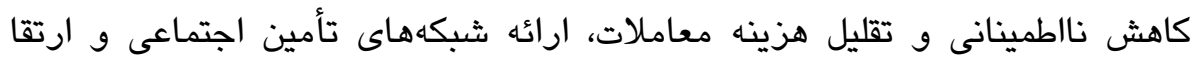

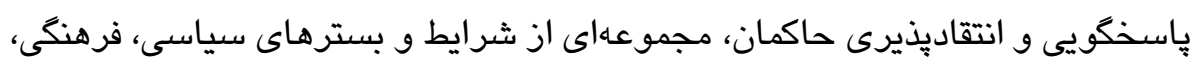

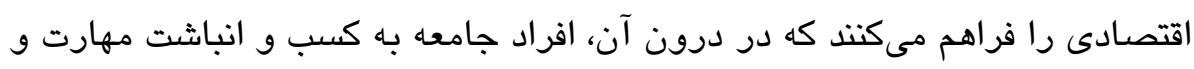

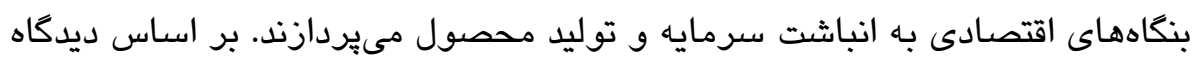

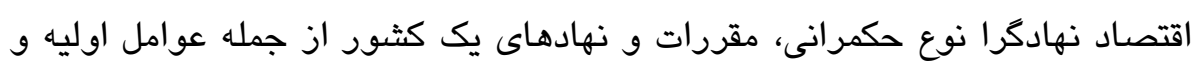

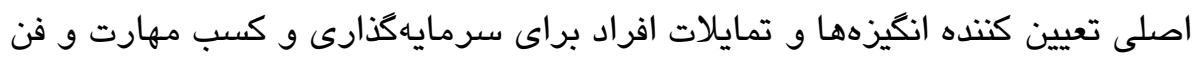
آورى در آن جامعه هستند كه همه اين عوامل منجر به موفقيت اقتصادى در توليد توليد

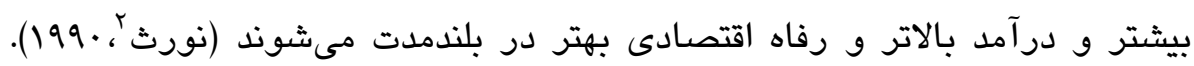

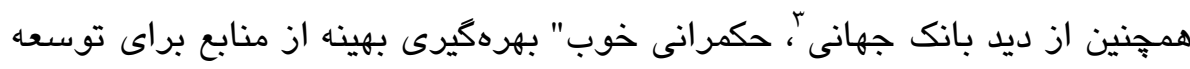

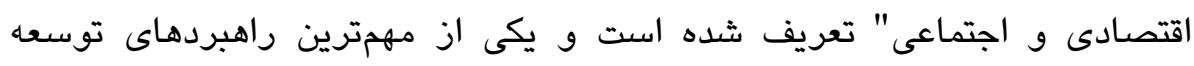

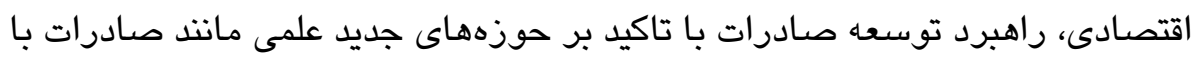

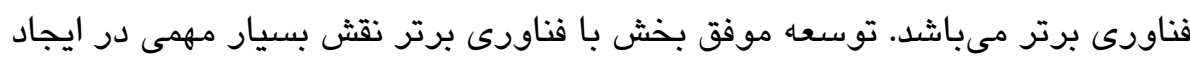

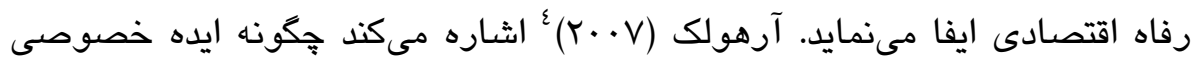

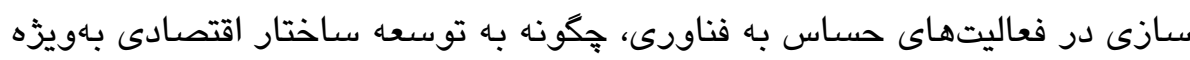

1- Coase

2- North

3- World Bank

4- Srholec 
در كثورهاى درحال توسعه كمك مىكند. آرجيبوكى و كوكو' (ع . (Y) بحث مىكنت ظرفيتهاى فناورى همواره، عنصر حياتى در رشد و رفاه اقتصادى هستند و كرجها توزيع ظرفيتهاى بالقوه فنى در سراسر جهان، ناهمكون است اما مديريت و سازمان دهى اين ظرفيتها، تاثير بسزايى در خلق موقعيتهاى جديد فناورى دارد. لذا رقابت

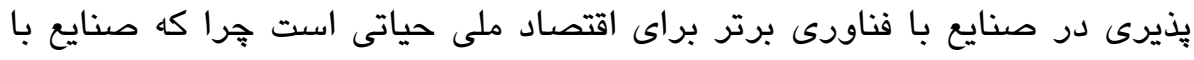

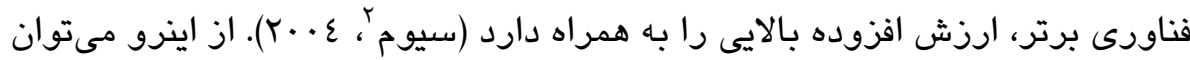

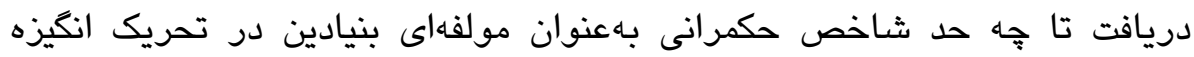
صاحبان عوامل توليد براى ورود به كسب و كارهاى مبتنى بر فناورى بالا با تعميم

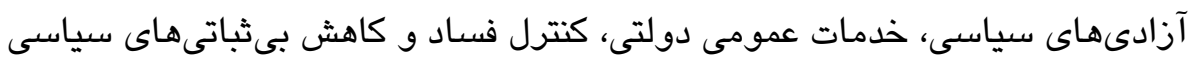
و اقتصادى مىتواند بر صادرات فناورى برتر تاثير داشته باشدئ در در ادامه مطالعات تجربى در اين زمينه ارائه مىشود

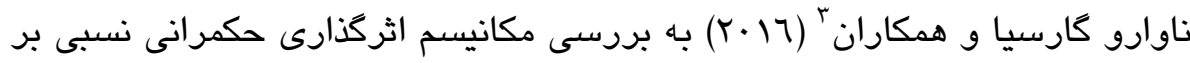

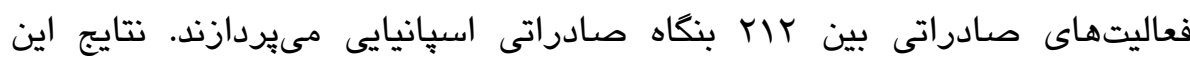

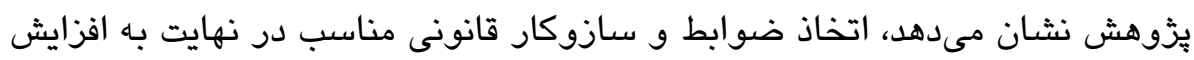

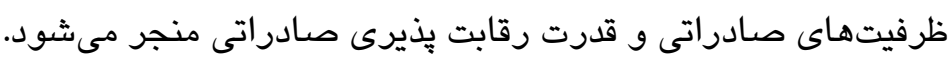

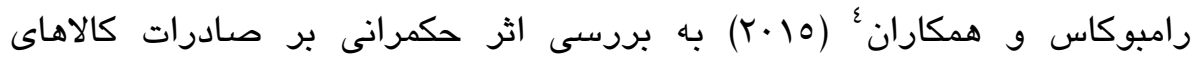

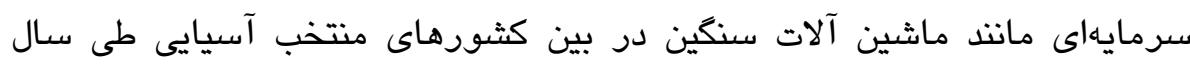

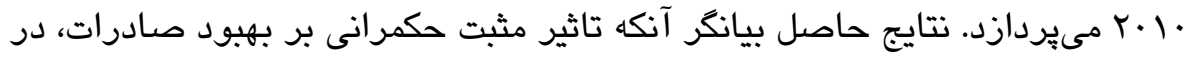

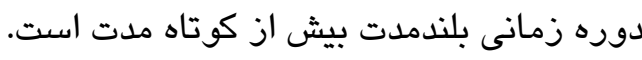

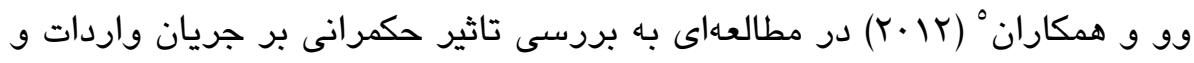

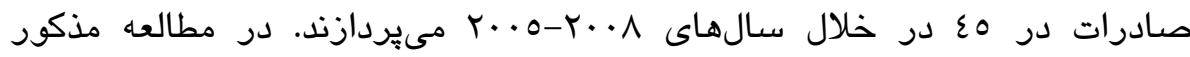
براساس شاخص حكمرانى كشورها بطوركلى به ب دسته (كثورهاى قانون مدار با

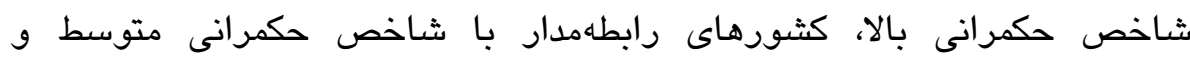

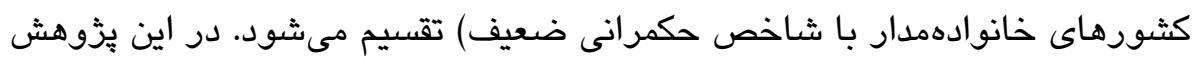

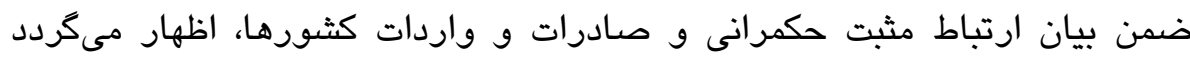

1- Archibugi and Coco

2- Seyom

3- Navarro-García

4- Rambocas

$5-\mathrm{Wu}$ 
ارتباط مثبت و معنىدارى مابين شاخص حكمرانى و سطح تجارت در كثورهاى

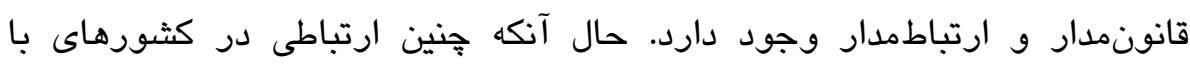
شاخص حكمرانى ضعيف ديده نمىشود.

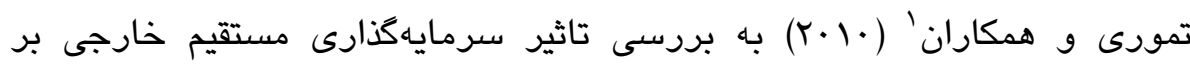

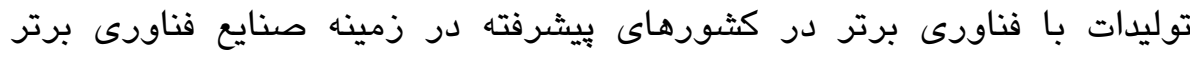

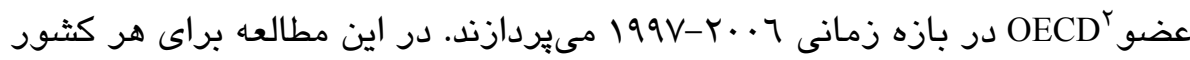
بصورت مجزا و براى كل نمونه با روش يانل ديتا تاثير سرمايهكذارى مستقيم

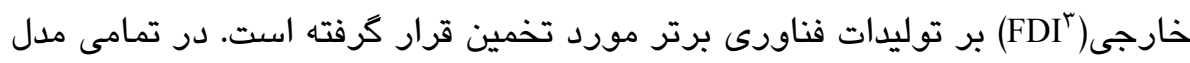
هاى تخمينى، تاثير FDI بر توليدات فناورى برتر، مثبت و معنادار مى باشثد.

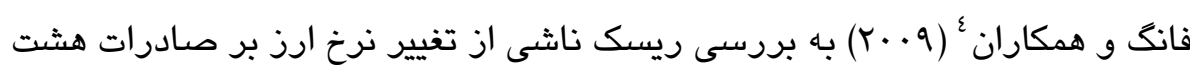

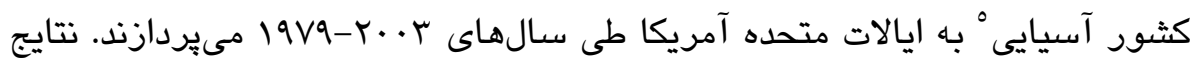

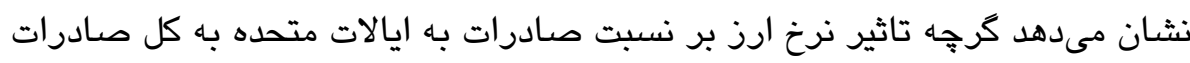

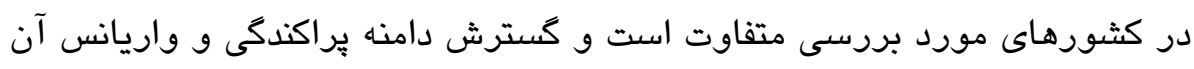

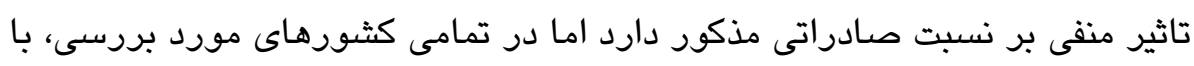

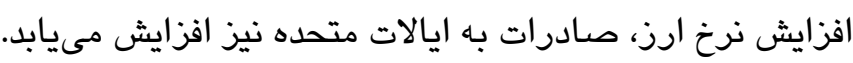

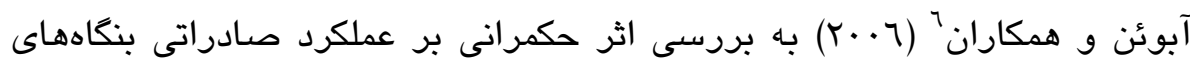

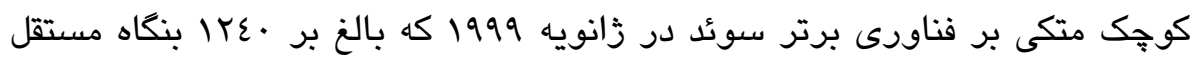

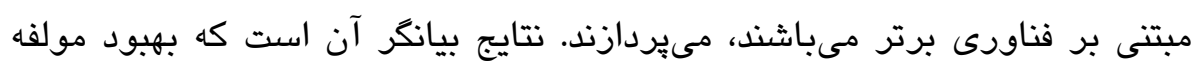

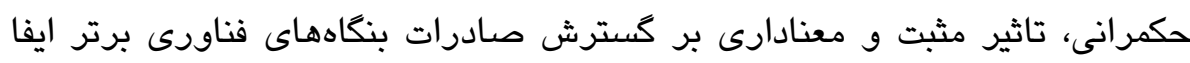

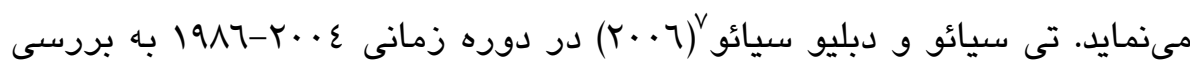

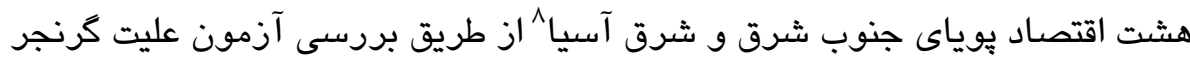

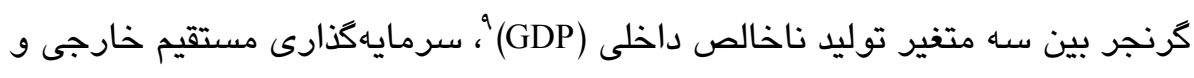

1 - Temouri

ז- كثور ها شامل بلزيك، آلمان، فرانسه، سوئد، هلند، انكلستان، ايالات متحده آمريكا و زاين مىباشند. 3- Foreign Direct Investment

4- W. Fang and

ه- كثور ها شـامل اندونزى، زاين، كره جنوبى، مالزى، فيلييين، سنكايور، تايوان و تايلند مىباشند.

6- L. Aaboen

7- F. S.T. Hsiao and M.C. W. Hsiao

1- كثور ها شـامل اندونزى، زاين، كره جنوبى، مالزى، فيليين، سنكايور، تايوان و تايلند مى باشند.

9- Gross Domestic Product 
و صادرات مىيردازند. نتايج بيانكر آن است كه توليد ناخالص داخلى و سرمايهكارى مستقيم خارجى تاثير مثبتى بر صادرات دارند، در حالى كه عكس اين رابطه، وجود

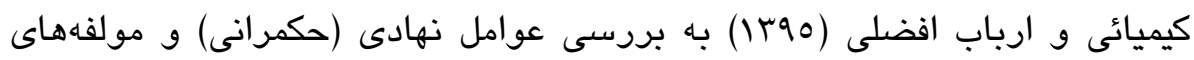
منتخب اقتصاد دانشبنيان (تحقيق و توسعه، فناورى اطلاعات و ارتباطات و هزينه

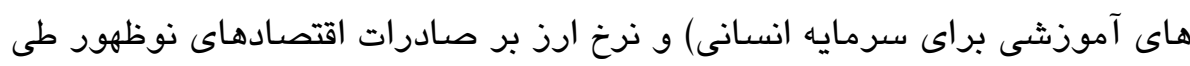

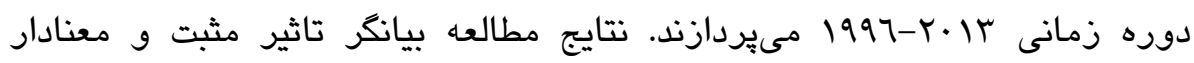
شاخص حكمرانى، نرخ ارز و مولفههاى اقتصاد دانشبنيان بر صادرات است.

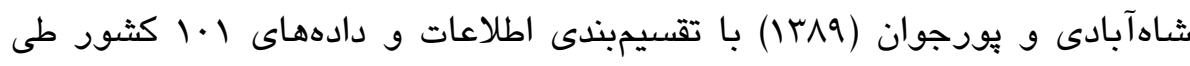

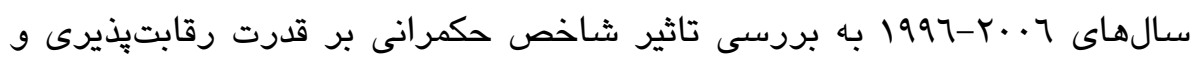

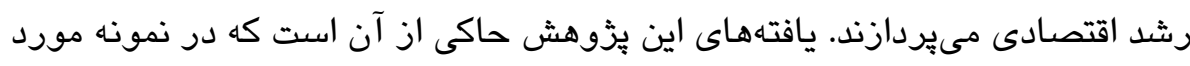

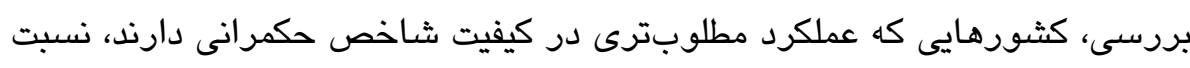

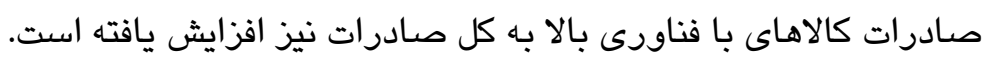

\section{معرفى متغيرها و ارائه مدل}

اكنون با توجه به مطالعات انجام شده، عوامل تعيين كنتده صادرات با فناورى برتر

$$
\text { بهورت زير معرفى مىشوند: باهن }
$$

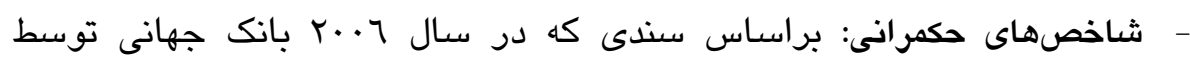

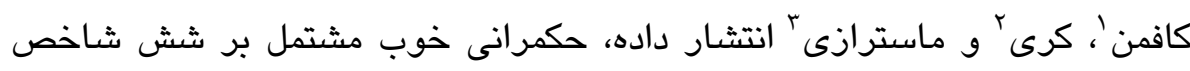

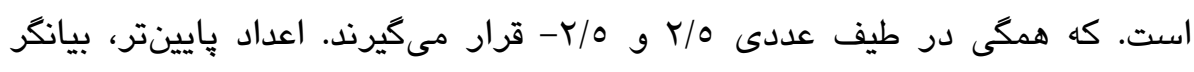

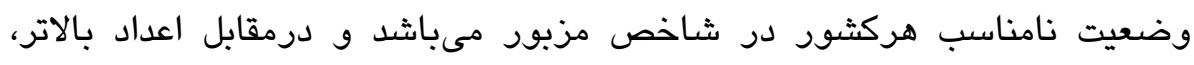

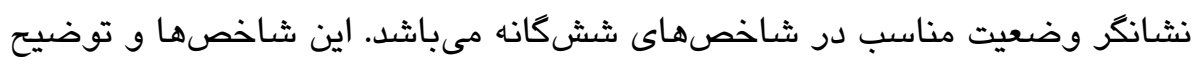

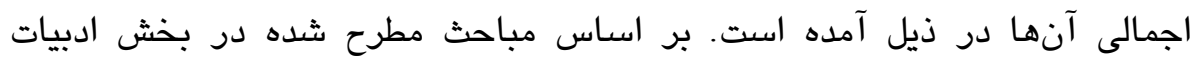

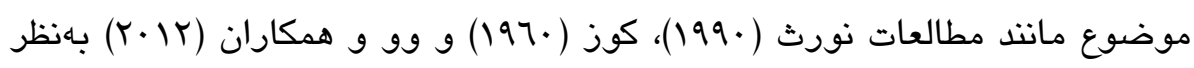

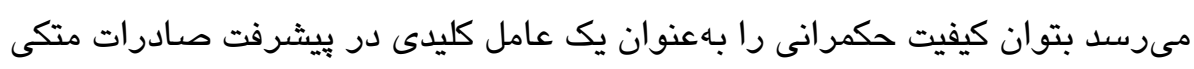

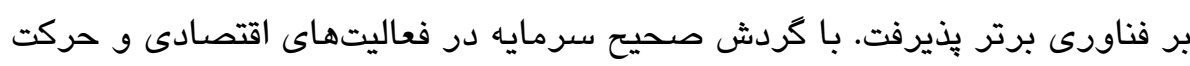

\section{1- Kaufmann}

2- Kraay

3- Mastruzzi 
به سمت فعاليتهاى دانشبنيان، بكاركيرى ابداعات، اختراعات و نوآورىها توسط كارفرمايان درجامعه كسترش مىيابد. در اين مطالعه، از ميانكين ساده شش شاخص

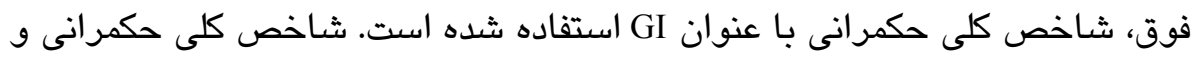

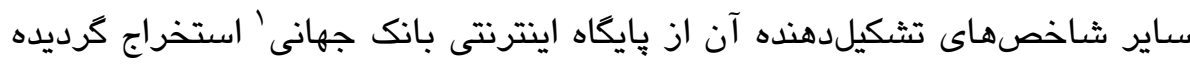

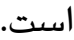

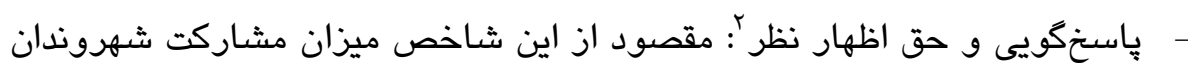

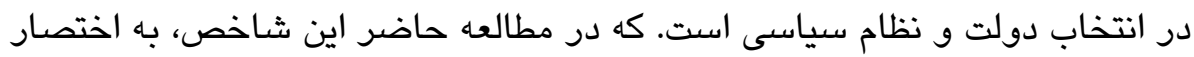
VOICE

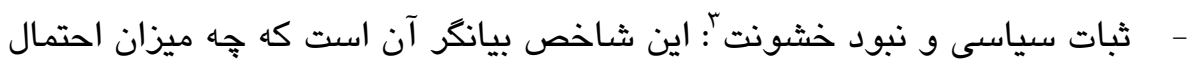

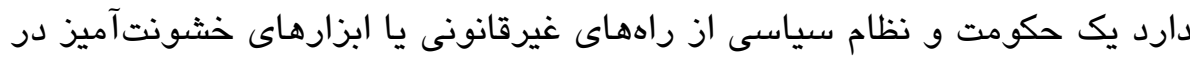

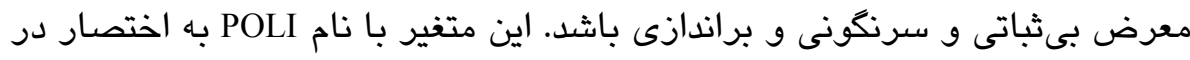
تخمينها لحاظ شده است.

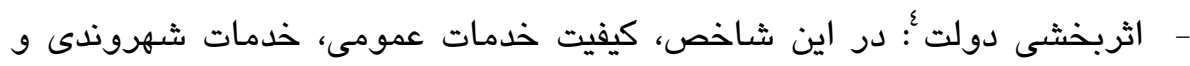

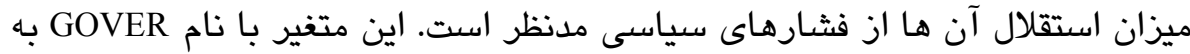

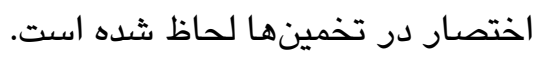
- كيفيت تنظيمكرى ؛ منظور از اين شاخص، توانمندى دولت درهات در تدوين و اجراى

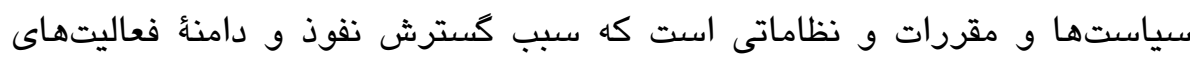

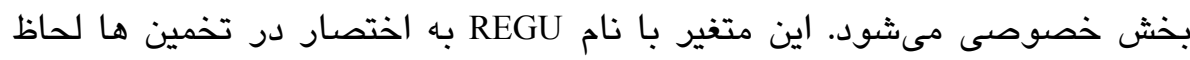
شده است.

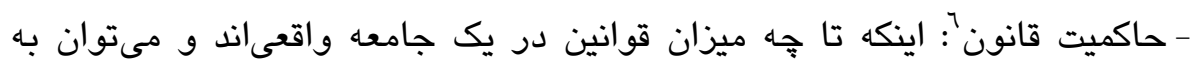
اجراى آنها اطمينان داشت با اين شاخص ارزيابى مىشود. اين متفير با عنوان RULE

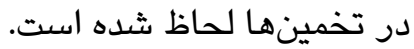

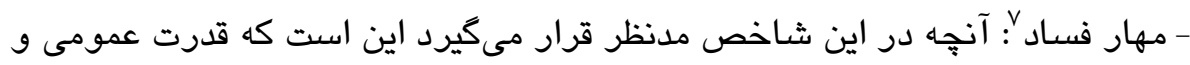

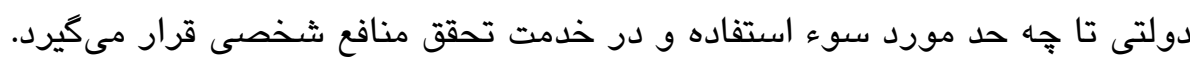

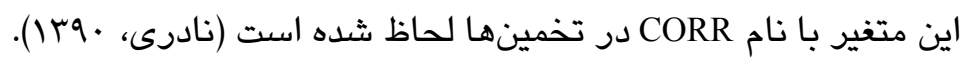

1- www.worldbank.org/ wdi/ gowernance:Governance Indicators Webpage 2- Voice and accountability

3- Political stability and absence of violence

4-Government effectiveness

5-Regulatory quality

6- Rule of law

7- Control of corruption 
- توليد ناخالص داخلى سرانه: در زمينه ارتباط بين صادرات و توليد، محققان

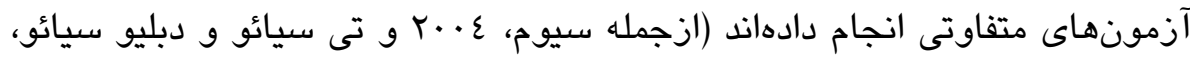

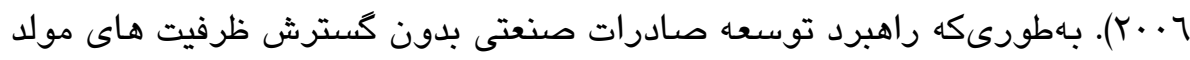

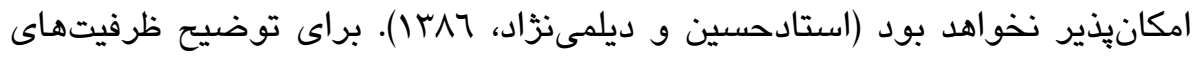

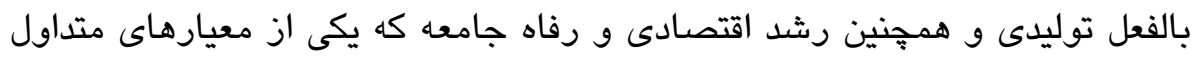

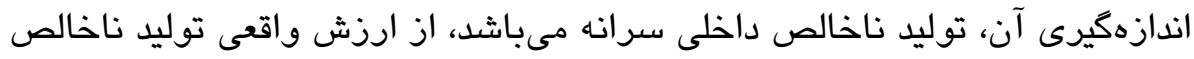

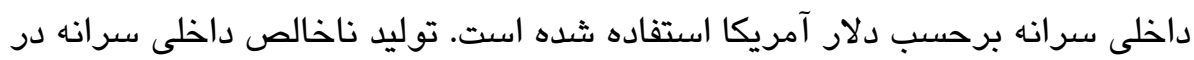

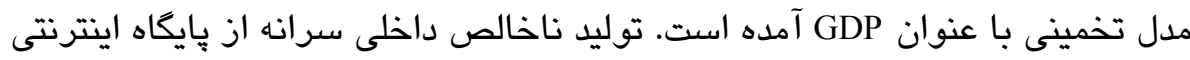

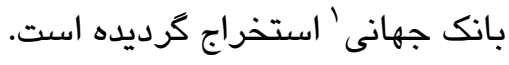

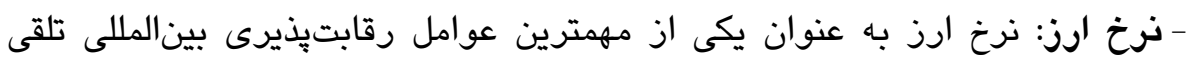

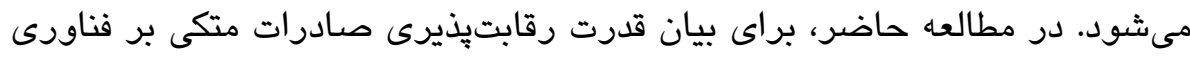
برتر از شاخص نرخ ارز رسمى هر كثور استفاده شده است. انتظار مىرود، نرخ ارز

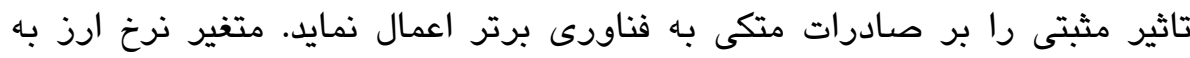

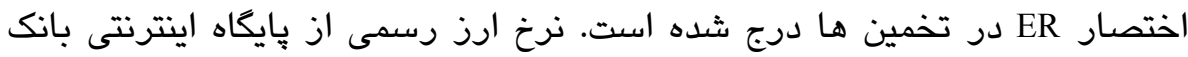
جهانى استخراج كرديده است. - سرمايهكذارى مستقيم خارجى: مطالعات صورت كرفته (از قبيل مطالعه تمورىى و و

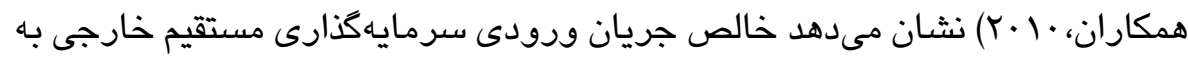

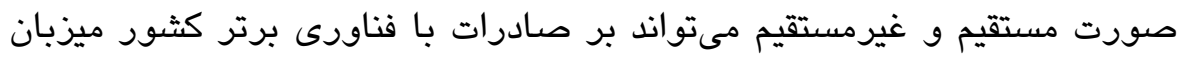

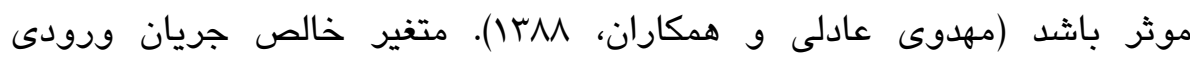

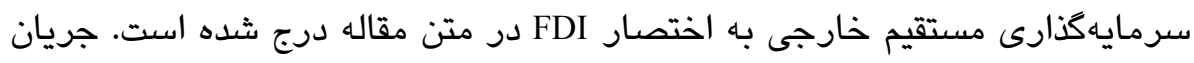
خالص ورودى سرمايهكذارى مستقيم خارجى پايكاه اينترنتى بانك جهانى استخراج كرديده است. بنابراين، به يشتوانه مبانى نظرى و مطالعات تجربى مانتد مطالعات وو و همكاران

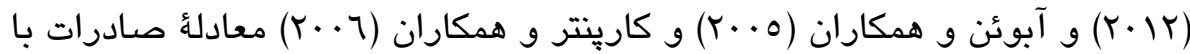

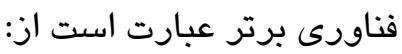
$H E X=f(G D P, E R, F D I, G I)(1)$ بر اين اساس بهجود در هر يك از اين شاخصهاى حكمرانى باعث افزايش و رشد

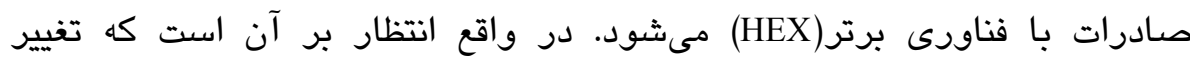


(افزايش) در GDP, ER, FDI, GI نيز طى يك دوره زمانى منجر به تغيير همسو (افزايش) بر HEX شود. به بيان ديكر: $\frac{\partial H E X}{\partial X_{i}} \succ 0, \quad \Rightarrow \quad X_{i}=G D P, E R, F D I, G I(2)$

بهطورىكه اشاره شد شاخص حكمرانى (GI) شامل شش شاخص پٍاسخكويى و حق

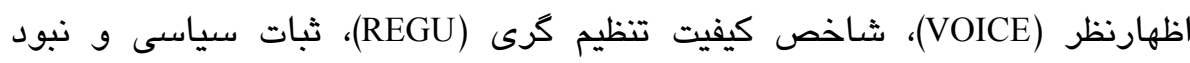
خشونت (POLI)، اثريخشى دولت (GOVER)، حاكميت قانون (RULE) و (RULE) مهار فساد (CORR)

GI =[GOVER, VOICE, REGU,POLI, RULE,CORR $]$ (3)

اكنون اكر معادله ا را بصورت زير در نظر كرفته و از طرفين آن لكاريتم طبيعى

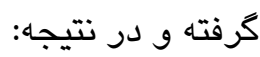

$\operatorname{LnHEX}_{i t}=\operatorname{LnA}+\theta_{1} \operatorname{LnGI}_{1 i t}+\theta_{2} \operatorname{LnGDP}_{2 i t}+\theta_{3} E R_{3 i t}+\theta_{4} F D I_{4 i t}+U_{i t}(4)$

از آنجاكه LnA مقدار ثابتى است لذا معادله ع را بهصورت زير مى توان بازنويسى نمود:

LnHEX $_{i t}=c+\theta_{1} L n G I_{1 i t}+\theta_{2} \operatorname{LnGDP_{2it}}+\theta_{3} E R_{3 i t}+\theta_{4} F D I_{4 i t}+U_{i t}(5)$

باتوجه به اينكه در اين مطالعه شاخص حكمرانى (GI) بر اساس رابطةٌ با، بهوسيل؛ شش شاخص تعريف و بررسى قرار مىشود، معادلأ ه نيز به هفت معادلأ مجزا

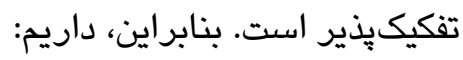

$\operatorname{LnHEX}_{i t}=c+\theta_{1} \operatorname{LnGOV}_{i t}+\theta_{7} \operatorname{LnGDP_{it}}+\theta_{8} E R_{i t}+\theta_{9} F D I_{i t}+\varepsilon_{i t}(5-1)$

LnHEX $_{i t}=c+\theta_{1} L_{n C O R R_{i t}}+\theta_{7} L n G D P_{i t}+\theta_{8} E R_{i t}+\theta_{9} F D I_{i t}+\eta_{i t}(5-2)$

$\operatorname{LnHEX}_{i t}=c+\theta_{2} \operatorname{LnGOVER}_{i t}+\theta_{7} \operatorname{LnGDP}_{i t}+\theta_{8} E R_{i t}+\theta_{9} F D I_{i t}+\beta_{i t}(5-3)$

LnHEX $_{i t}=c+\theta_{3} \operatorname{LnPOLI}_{i t}+\theta_{7} \operatorname{LnGDP}_{i t}+\theta_{8} E R_{i t}+\theta_{9} F D I_{i t}+\delta_{i t}(5-4)$

LnHEX $_{i t}=c+\theta_{4} \operatorname{LnREGU}_{i t}+\theta_{7} \operatorname{LnGDP}_{i t}+\theta_{8} E R_{i t}+\theta_{9} F D I_{i t}+\mu_{i t}(5-5)$

$\operatorname{LnHEX}_{i t}=c+\theta_{5} \operatorname{LnRULE}_{i t}+\theta_{7} \operatorname{LnGDP}_{i t}+\theta_{8} E R_{i t}+\theta_{9} F D I_{i t}+\partial_{i t}(5-6)$

LnHEX $_{i t}=c+\theta_{6}$ LnVOICE $_{i t}+\theta_{7} \operatorname{LnGDP}_{i t}+\theta_{8} E R_{i t}+\theta_{9} F D I_{i t}+\varphi_{i t}(5-7)$

در معادلات فوق، ضرايب

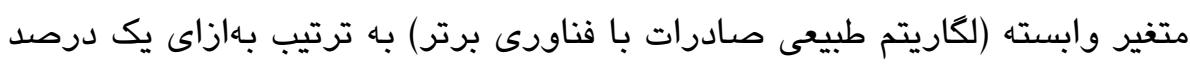

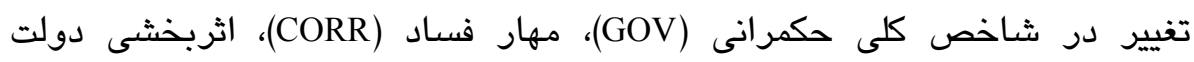

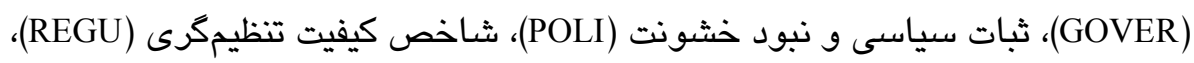


حاكميت قانون (RULE) و شاخص پֶاسخكويى و حق اظهارنظر (VOICE) است. ضرايب هر يك از متفيرهاى توليد ناخالص داخلى سرانه (GDP)، نرخ ارز (ER) و سرمايه كذارى مستقيم خارجى (FDI) هستند.

\section{تحليل و تقسير نتايج}

اولين كام در برآورد مدلهاى دادههاى تابلويى تعيين نمودن قيود وارد شده بر مدل اقتصادسنجى است. بهعبارت ديكر، ابتدا بايد مشخص كنيم رابطأ ركرسيونى در

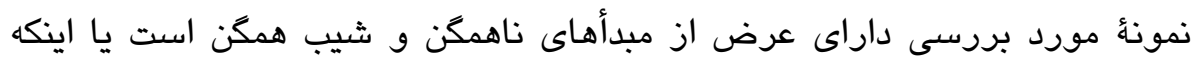

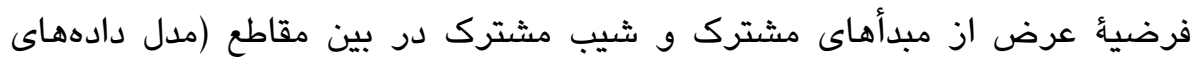
تلفيقى) يذيرفته مىشود. بدينمنظور از آزمون F استفاده مىشود. بر اساس اين

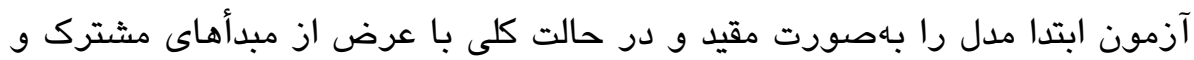

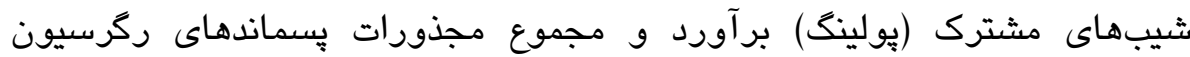

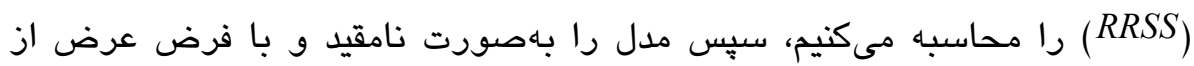
مبدأهاى ناهمكَ در بين مقاطع و شيبهاى مشترك برآورد و مجموع مجذورات

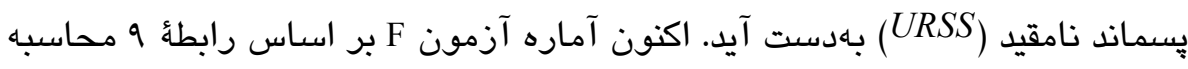

$$
F_{(N-1, n t-n-k)}=\frac{[R R S S-U R S S] /(n-1)}{[U R S S] /(n t-n-k)}
$$
كرديده و با مقدار F جدول مقايسه مىشود:

بهطورىكه n تعداد مقاطع و كثورها، t دوره زمانى و k تعداد متغيرهاى توضيحى مدل هستند. در صورتىكه مقدار F محاسبه شده در رابطأ 9 از Fد جدول با درجات

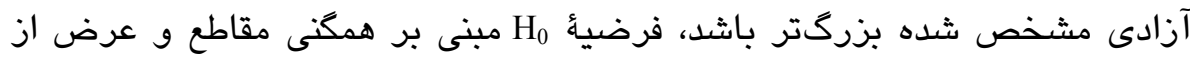

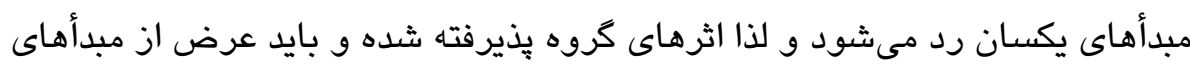

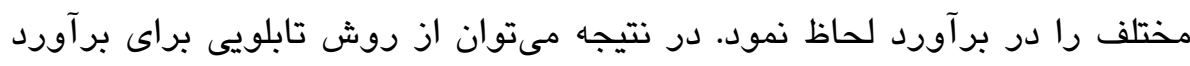

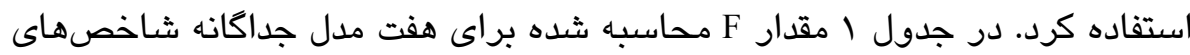

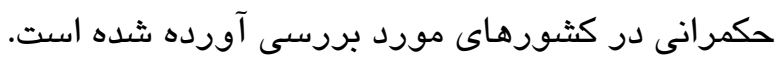


جدول ا - نتايتج آزمون F ليمر براى بررسى مدلهاى تلفيقى و تابلويى

\begin{tabular}{|c|c|c|c|c|c|c|c|}
\hline مدل & مدل 1 & مدل r & مدل r & مدل ع & مدل 0 & مدل 7 & مدل V \\
\hline آماره & $170 / 04$ & $\mid V Y / I \varepsilon$ & $17 \cdot / 1 \mathrm{~V}$ & $\mid V T / \Lambda \varepsilon$ & $10 Y / \cdot r$ & $100 / 0$ & $|\varepsilon \tau / \wedge|$ \\
\hline Fطمح احتمال F & {$[\cdot / \cdots]$} & {$[\cdot / \cdots]$} & {$[\cdot / \cdots]$} & {$[\cdot / \cdots]$} & {$[\cdot / \cdots]$} & {$[\cdot / \cdots]$} & {$[\cdot / \cdots]$} \\
\hline
\end{tabular}

مأخذ: يافتهایى يخوهش

با توجه به مقادير F براى كثورهاى مورد مطالعه در جدول و احتمال محاسبه شده براى آماره F اثرهاى كروهى در بين كثورها يذيرفته مىشود و و بنابراين، بايد در درد

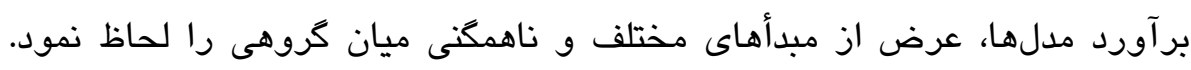

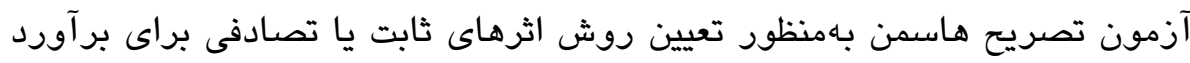

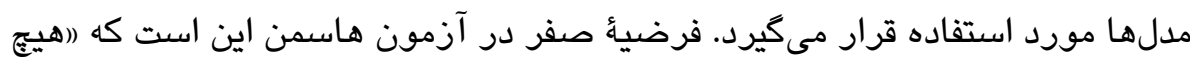

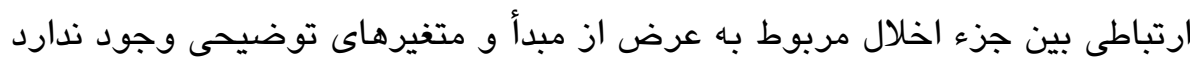

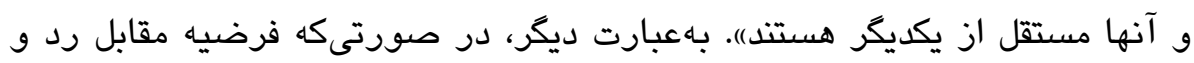
فرضيءٔ صفر يذيرفته شود، روش اثرات تصادفى سازكار و روش اثرات ثابت

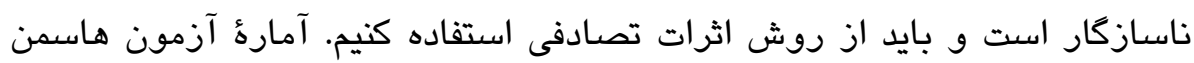

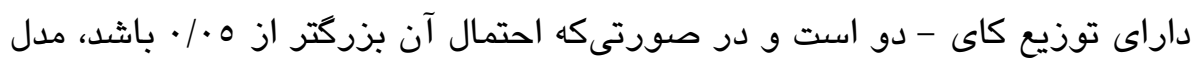

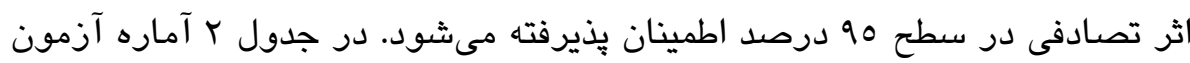

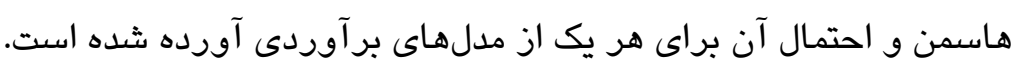

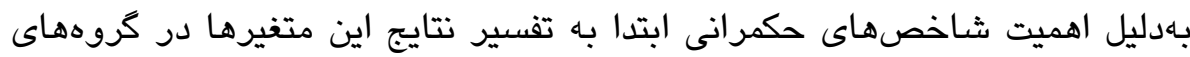
مورد بررسى مىيردازيم. طبق تخمين هاى موجود در جدول، ضريب متغيرهاى

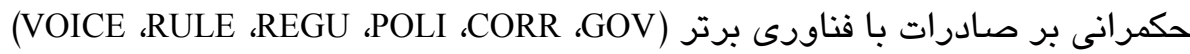
مثبت و در سطح اطمينان 99٪ يذيرفته مىشوند و همجنين تاثير شاخص اثربخشى دولت بر صادرات با فناورى برتر منفى و معنادار مىباشد. از اينرو بهبود

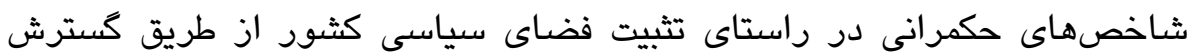
مشاركت مردمى در امور سياسى، وضع قوانينى براى حمايت از صاحبان مالكيتهاى مادى و معنوى و افزايش ضمانت اجرايى براى قوانين مصوب قضايى بهواسطه تاثير بر ساختار انكيزشى عاملين اقتصادى و افزايش تمايل براى بكاركيرى سرمايهاى علمى و انسانى در مسير توليد محصولات داخلى، تخصيص منابع را بهسمت توليدات دانش محور و درنهايت افزايش ارزش صادرات مبتنى بر فناورى برتر معطوف

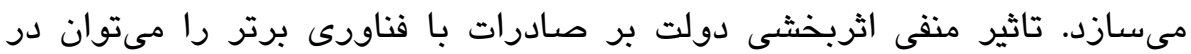


ماهيت اقتصادى كثورهاى نفتى كه غالب كثورهاى عضو G15 را تشكيل مىدهند،

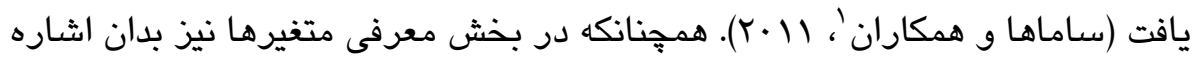
كرديد، اثربخشى دولت به كيفيت خدمات شهروندى ارائه شده توسط دولت و همجنين استقلال سياستهاى كلان اقتصادى دولت از فشارهاى سياسى اطلاق مىكردد. بنظر مىرسد يكى از دلايل منفى بودن اين شاخص وابستكى قابل توجه دولت در برخى از كثورهاى مورد مطالعه به ثروت نفت است؛ زيراكه وجود ثروت نفت و اتكاى بيش دون لفي

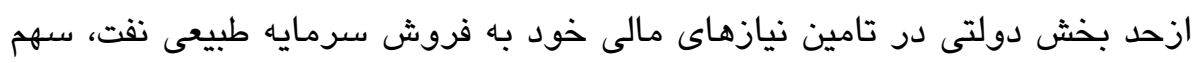

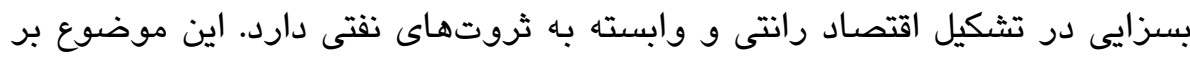

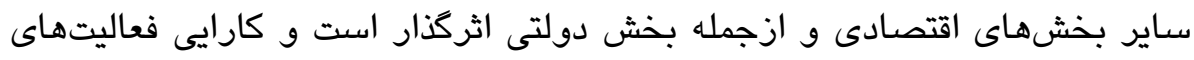

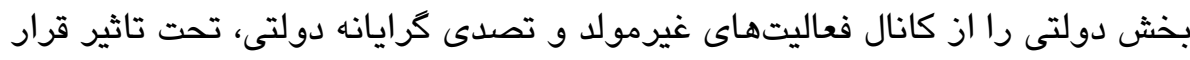

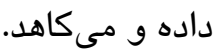
سه متغير كنترل شامل توليد ناخالص داخلى سرانه، خالص جريان ورودىى سرمايه

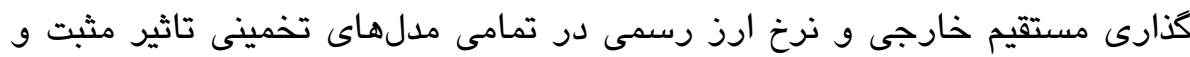
معنادارى را از نظر آمارى بر ارزش صادرات با فناورى برتر دارند. در اكثر

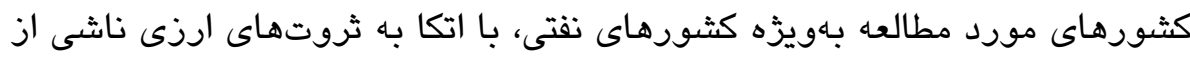

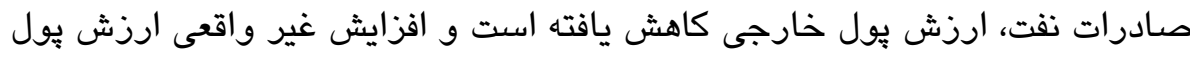

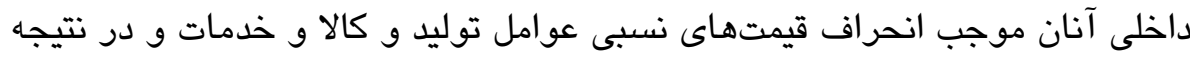
تخصيص غيريهينه منابع و كاهش قدت رقابتيذيرى بهويزه در حوزه فعاليتهاى

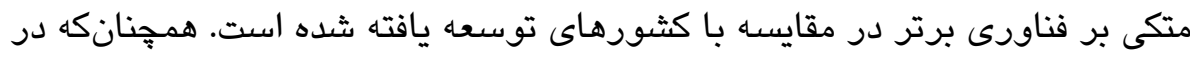

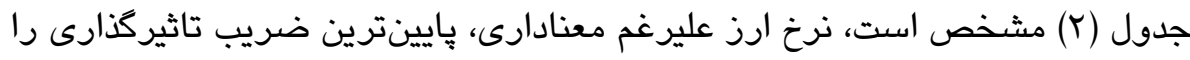
در بين سه متفير استاندارد داراست كه به اتكاى عرضه ثروت نفت و برقرارى نرخ

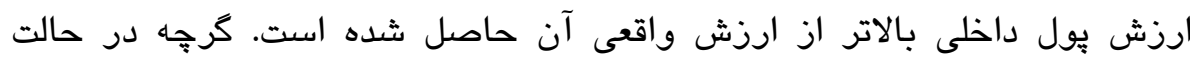

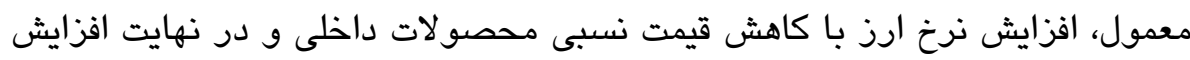

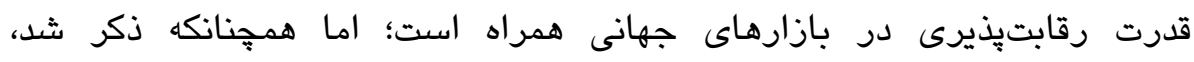

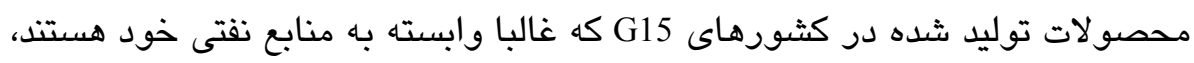

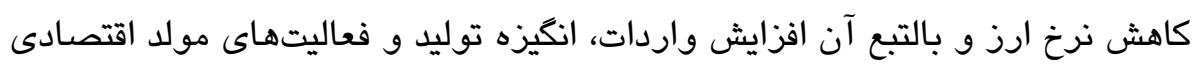

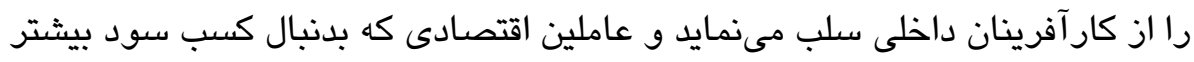




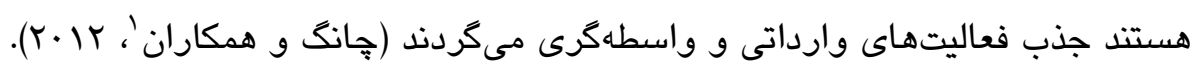
ازاينرو، به سبب وابستكى به منابع نفتى و تقويت غيرواقعى يول داخلى و درنهايت

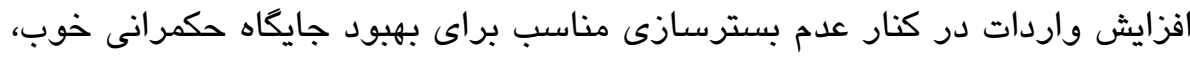

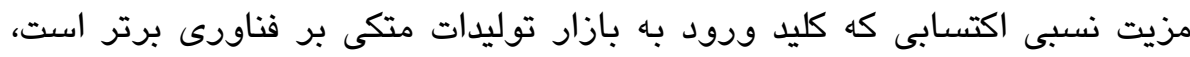
دست يافتنى نخواهد بود.

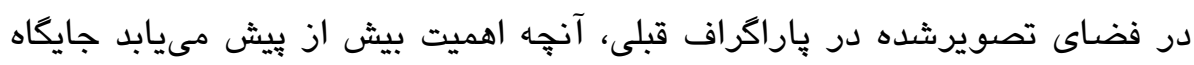

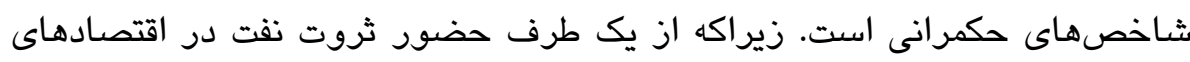

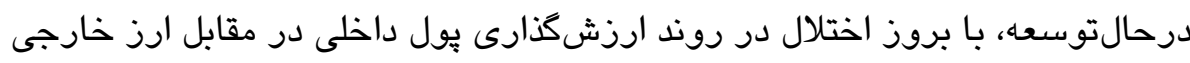

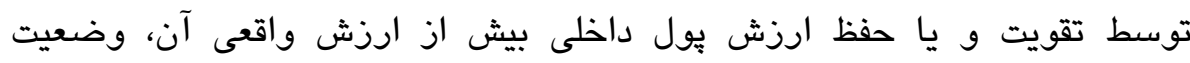

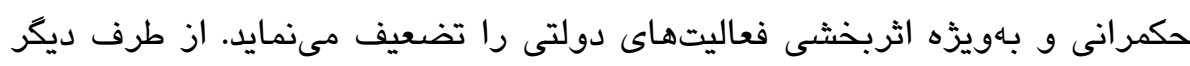

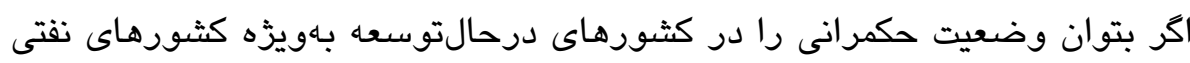

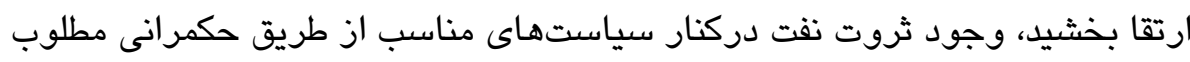

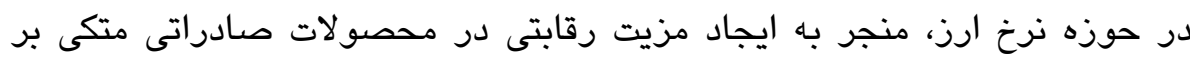

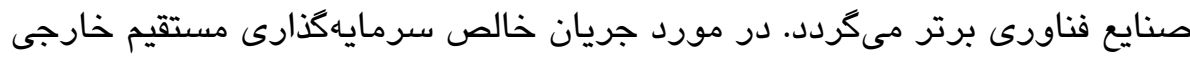

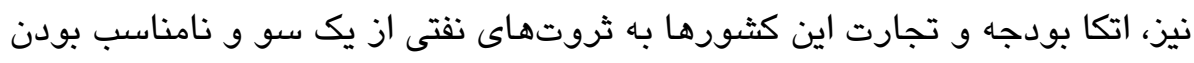

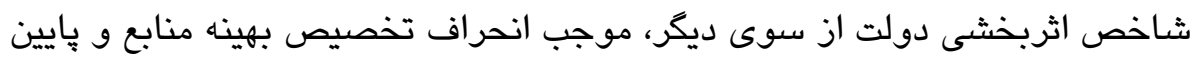

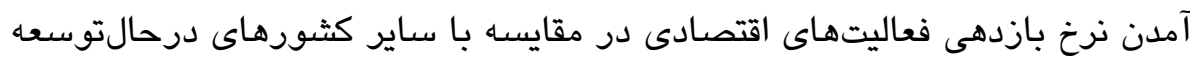

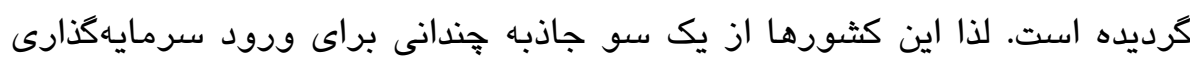

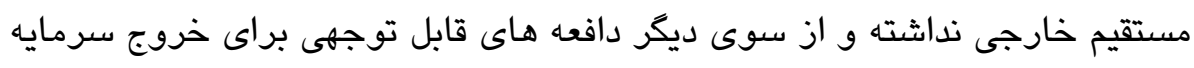

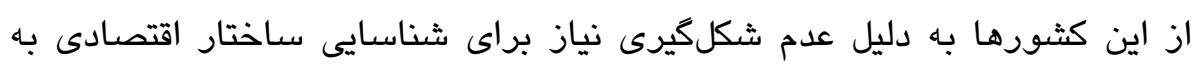

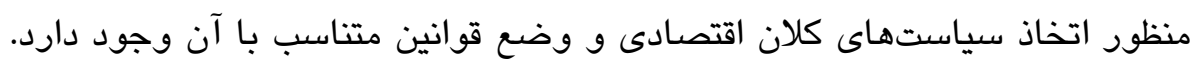

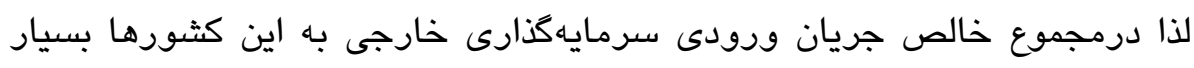

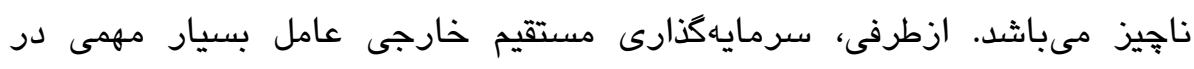

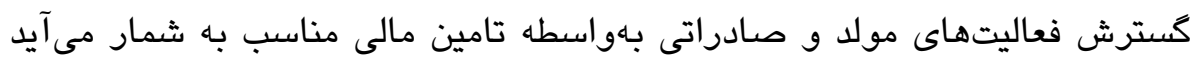

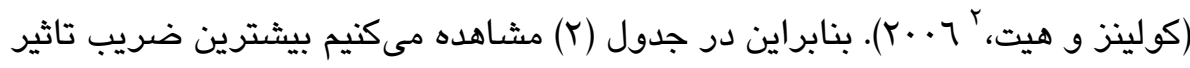

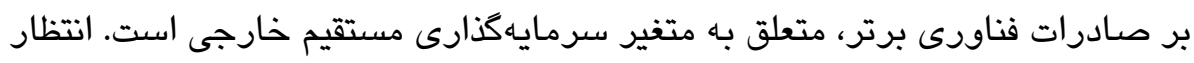

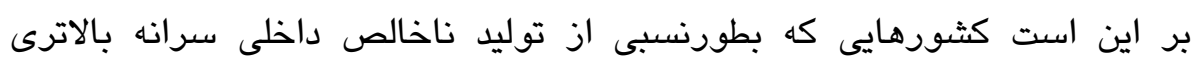

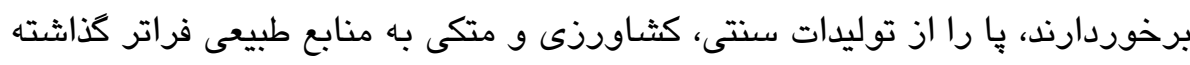

1- Chang

2- Collins and Hitt 
اند و با كسب مزيت در توليدات متكى بر فناورى برتر، در بازارهاى كسترده توليدات

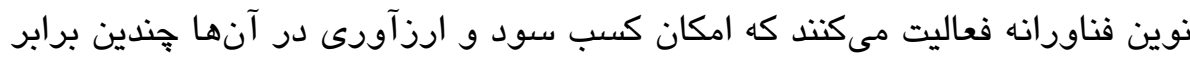
بازارهاى سنتى است. بنابراين ملاحظه مىكردد، در جدول (Y)، تاثير متغير توليد ناخالص داخلى بر صادرات فناورى برتر مثبت مىباشد.

جدول ץ- نتايج برآورد معادلهُ صادرات با فناورى برتر كشورهاى عضو G15 به روش اثرات تصادفى

\begin{tabular}{|c|c|c|c|c|c|c|c|}
\hline \multicolumn{8}{|c|}{ متغير وابسته Ln (HEX) } \\
\hline متغيرهاى توضيحى & مدل 1 & مدل r & مدل r م & مدل ب & مدل ه ه & مدل 9 & 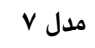 \\
\hline Ln GDP & 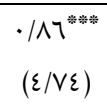 & 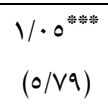 & $\begin{array}{l}r / \backslash \varepsilon^{* * * * *} \\
(V / V Y)\end{array}$ & 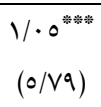 & 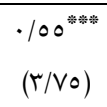 & $\begin{array}{l}\cdot 10 \Lambda^{\text {䓪漛 }} \\
(\varepsilon / \cdot r)\end{array}$ & $\begin{array}{l}\cdot 10 r^{* * \ldots * m} \\
(r / 00)\end{array}$ \\
\hline FDI & 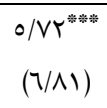 & 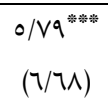 & 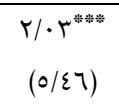 & 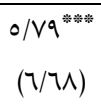 & 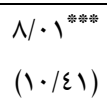 & 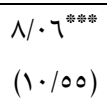 & $\begin{array}{l}\mathrm{V} / \mathrm{V} \mathrm{T}^{* * \ldots * \ldots} \\
(1 \cdot / \cdot \wedge)\end{array}$ \\
\hline ER & $\begin{array}{l}\cdot / \cdot 1^{\text {草草 }} \\
(7 / 17)\end{array}$ & $\begin{array}{l}\cdot / \cdot 1^{\text {税 }} \\
(0 / 7 \varepsilon)\end{array}$ & 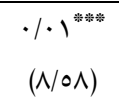 & $\begin{array}{l}\cdot / \cdot 1^{\text {䌨 }} \\
(0 / 7 \varepsilon)\end{array}$ & 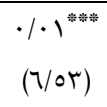 & 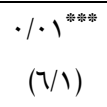 & 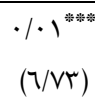 \\
\hline Ln GOV & 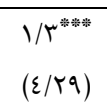 & - & - & - & - & - & - \\
\hline Ln CORR & - & $\begin{array}{l}\cdot / 0 \varepsilon^{* * *} \\
(1 / 91)\end{array}$ & - & - & - & - & - \\
\hline Ln GOVER & - & - & 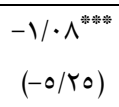 & - & - & - & - \\
\hline Ln POLI & - & - & - & $\begin{array}{l}\cdot 10 \varepsilon^{* * *} \\
(1 / 91)\end{array}$ & - & - & - \\
\hline Ln REGU & - & - & - & - & 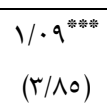 & - & - \\
\hline Ln RULE & - & - & - & - & - & 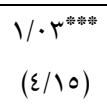 & - \\
\hline Ln VOICE & - & - & - & - & - & - & $\begin{array}{l}1 / 1^{\text {*:*** }} \\
(\varepsilon / 0 \varepsilon)\end{array}$ \\
\hline مقدار ثابت & $\begin{array}{l}\varepsilon / 9 \varepsilon^{* * * * * m} \\
(9 / / \wedge)\end{array}$ & $\begin{array}{l}\varepsilon / \Upsilon \Lambda^{* * * m} \\
(\Lambda / \vee)\end{array}$ & $\begin{array}{l}1 / \cdot 1 \\
(1 / 19)\end{array}$ & $\begin{array}{l}\varepsilon / \Upsilon \Lambda^{* * * * m} \\
(\Lambda / \vee)\end{array}$ & 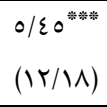 & $\begin{array}{l}0 / 07^{\text {*as:m }} \\
(1 \mathrm{~K} / \mathrm{YO})\end{array}$ & $\begin{array}{l}0 / V \varepsilon^{* * * * \ldots} \\
(I Y / 09)\end{array}$ \\
\hline آزمون $\chi^{2}$ هاسمن & $\begin{array}{l}\cdot / 11 \\
{[\cdot / 90]}\end{array}$ & $\begin{array}{l}\cdot / 01 \\
{[\cdot / \mathrm{V0}]}\end{array}$ & $\begin{array}{l}\cdot / 0 r \\
{[\cdot / V V]}\end{array}$ & $\begin{array}{l}\cdot / 01 \\
{[\cdot / \mathrm{VO}]}\end{array}$ & $\begin{array}{l}0 / 09 \\
{[\cdot / \cdot 7]}\end{array}$ & $\begin{array}{c}0 / Y 1 \\
{[\cdot / \cdot V]}\end{array}$ & $\begin{array}{c}r / r \\
{[\cdot / 19]}\end{array}$ \\
\hline
\end{tabular}

*ماخذ: يافته هاى بذّوهش

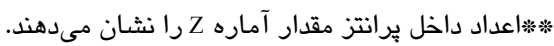

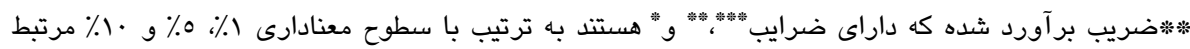




\section{نتيجه گيرى و توصيه هاى سياستى}

آنجه كه امروزه توان ملى و اقتصادى كثورها را تحت تاثير قرار مىدهد، هُخونكى

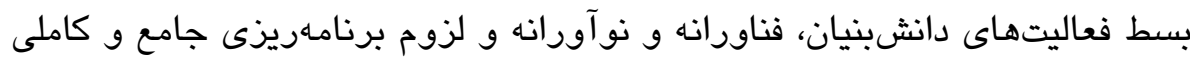

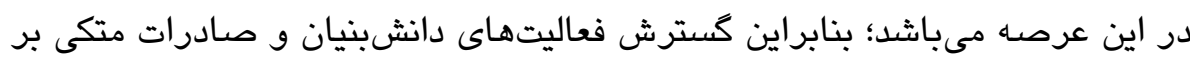

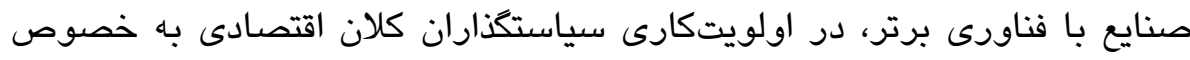

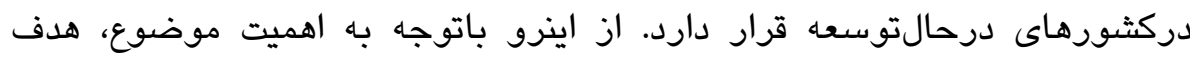

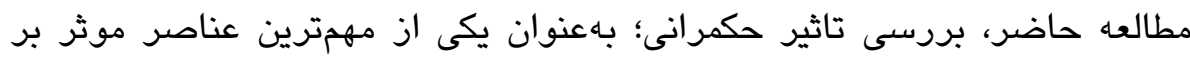

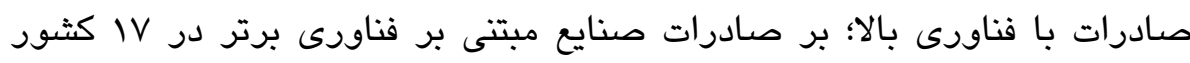

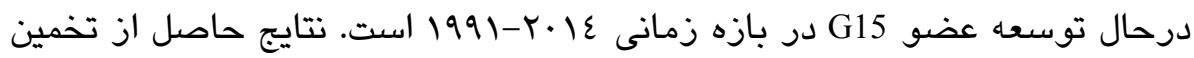
نماكر آن است كه شاخصهاى دكمرانى شامل شاخص كلى حكمرانى، شاخص

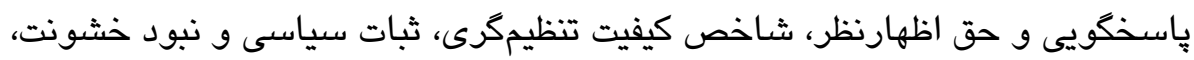

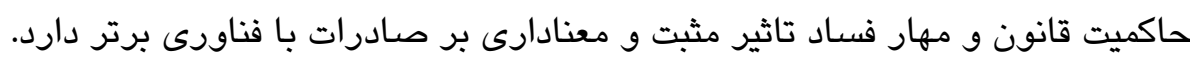

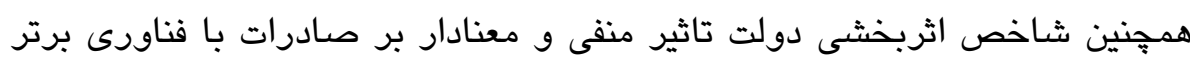

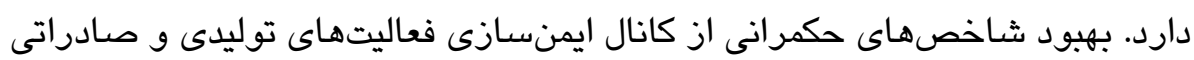

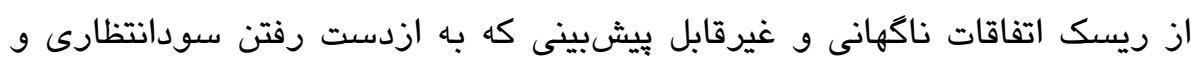

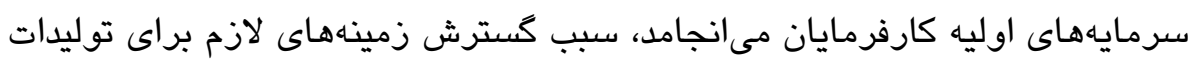

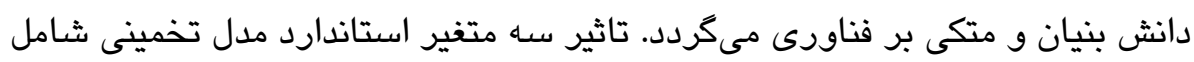

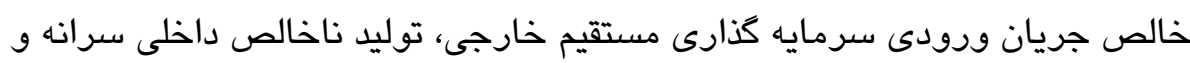

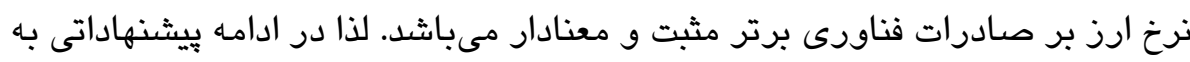

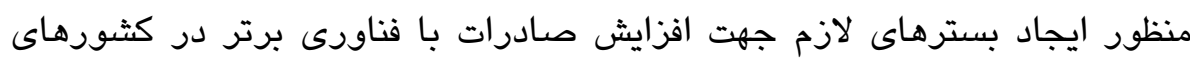
مورد مطالعه ارائه مىكردد:

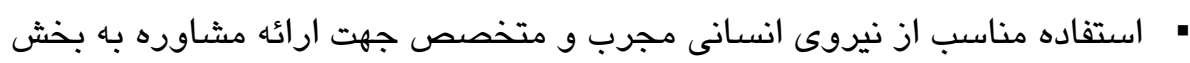

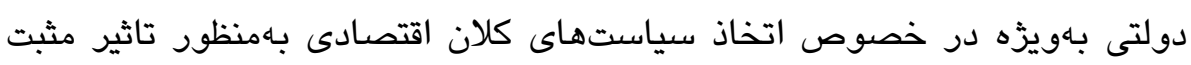

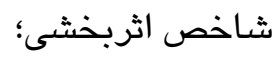
• تدوين قوانينى جهت كنترل، كاهش و جلوكيرى از بروز اختلاس و فساد در

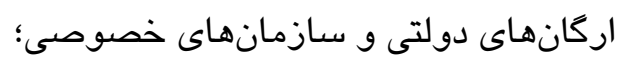

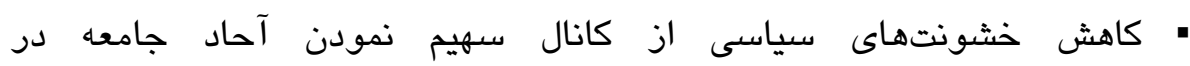

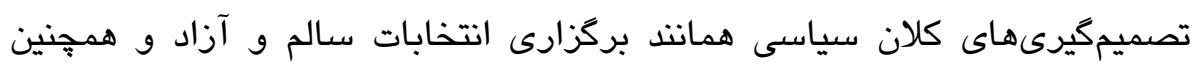

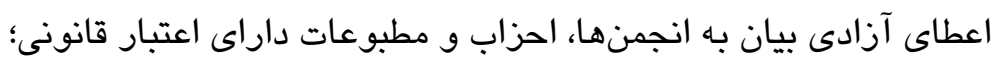




$$
\begin{aligned}
& \text { • اتخاذ سياستهاى كلان اقتصادى باثبات به منظور كاهش حوادث غيرقابل }
\end{aligned}
$$

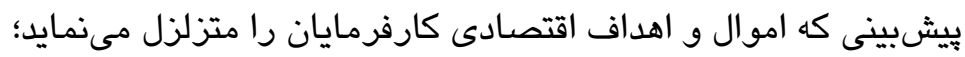

$$
\begin{aligned}
& \text { • ايجاد سازمانهايى كه بطور مداوم بر عملكرد دستكاههاى قضايى و اجرايى داني } \\
& \text { نظارت داشته باشند؛ } \\
& \text { • تعيين و حمايت از نرخ ارز در سطحى كه قدرت رقابتيذيرى محصولات داخلى در } \\
& \text { مقايسه با رقباى خارجى حفظ كردد؛ } \\
& \text { • ايجاد جذابيت طرحهاى صادرات با فناورى برتر داخلى براى صاحبان }
\end{aligned}
$$

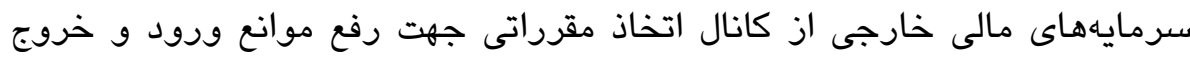

$$
\begin{aligned}
& \text { سرمايه كذارىهاى مستقيم خارجى همانت كاهش بروكراسى ادارى و ارائه تسهيلات }
\end{aligned}
$$

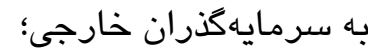

$$
\begin{aligned}
& \text { • كاهش وابستكى دولتى به درآمد حاصل از فروش نفت در كثورهائ نفتى از }
\end{aligned}
$$

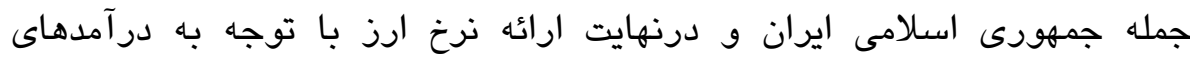

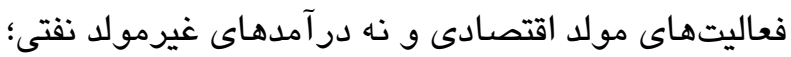

$$
\begin{aligned}
& \text { فناورى برتر ضرورى بنظر مىرسد. }
\end{aligned}
$$

\section{منابع و مآخذ}

1- Aaboen, L., Lindelo, P., Von Kochc, C. and Lofsten, H. (2006). Corporate governance and performance of small high-tech firms in Sweden. Technovation, 26(8), 955-968.

2- Archibugi, D. and Coco, A. (2004). A new indicator of technological capabilities for developed and developing countries (ArCo). World Development, 32(4), 629654.

3- Behkish, M. (2006). Iranian economy in the basis of globalization. $4^{\text {th }}$ Edition, Ney Publishing, Tehran; Iran.

4- Coase, R. (1937). The nature of the firm. Economica, 4(16), 386-405.

5- Collins, J. D., and Hitt, M. A. (2006). Leveraging tacit knowledge in alliances: The importance of using relational capabilities to build and leverage relational capital. Journal of Engineering and Technology Management, 23(3), 147-167.

6- Chang, S.J., Chung, J., and Moon, J. J. (2012). When did wholly owned subsidiaries performed better than joint ventures. Strategic Management Journal, 34(3), 317-337.

7- Fang, W.S., YiHao, L. and Miller, S.M. (2009). Does exchange rate risk affect exports asymmetrically? Asian evidence. Journal of International Money and Finance, 28(2), 215-239. 
8- Hsiao, F. S.T. and Hsiao, W.M.C. (2006). FDI, exports, and GDP in East and Southeast Asia-Panel data versus time-series causality analyses. Journal of Asian Economics, 17(6), 1082-1106.

9- Kaufmann, D. and Kraay, A. (2002). Growth without governance. World Bank Policy Research, Working Paper. Retrieved from http://siteresources.worldbank.org/INTWBIGOVANTCOR/Resources/growthgov.p df.

10- Kaufmann, D., Kraay, A. and Mastruzzi, M. (2004). Governance matters III: governance indicators for 1996, 1998, 2000 and 2002. The World Bank Economic Review, 18(2), 253-287.

11- Khodadad Hoseini, S. H. and Khodami, S. (2010). Internet effect on orientation of export channels in small and medium enterprises. Business Management Exploration Journal, 2(3), 1-26.

12- Kimiaei, F and Arbab Afzali, M. (2016). The impact of governance and knowledge economy factors on the emerging economies' exports. Quarterly Journal of Financial and Economic Policies, 13(6), 114-95.

13- Meidari, A. (2015). Good Governance, a review of the thesis for a Ph.D. in Economics. Business Review. 4(15), 143-149.

14- Meidari, A. and Kheirkhahan, (2004). Good governance: A basis for development. Research Center of Islamic Consultative Assembly, Tehran; Iran.

15- Naderi, M. (2011). Good governor: Introducing and brief criticism. Islam and Management Research, 1(1), 93-69.

16- Navarro-García, A., Sánchez-Franco, M.J., and Rey-Moreno, M. (2016). Relational governance mechanisms in export activities: Their determinants and consequences. Journal of Business Research, 69(11), 4750-4756.

17- North, D. C. (1990). Institutions, institutional change and economic performance. Cambridge, Cambridge University Press.

18- Ostad Hosein, R. and Deilaminejad, R. (2007). Investigating and determining the factors affecting the export of intermediary and primary goods of the industrial sector. Economic Journal, 73(10), 33-64.

19- Rambocas, M., Meneses, R., Monteiro, C. and Quelhas Brito, P. (2015). Direct or indirect channel structures. Evaluating the impact of channel governance structure on export performance. International Business Review, 24(1), 124-132.

20- Samaha, S., Palmatier, R. W., and Dant, R. P. (2011). Poisoning relationships: Perceive unfairness in channels of distribution. Journal of Marketing, 75(3), 99-117. 21- Secretariat of the expediency discretion council, Report of the Scientific, Cultural and Social Commission, (2004), Tehran; Iran.

22- Seyoum, B. (2004). The role of factor conditions in high-technology exports: an empirical examination. Journal of High Technology Management Research, 15(1), $145-162$.

23- Shahabadi, A., and Poorjavan, A. (2010). Governance, competitiveness and economic growth in selected countries. Scientific Journal of Extension Strategy Yas, 22(5), 129-168.

24- Srholec, M. (2007). High-tech exports from developing countries: a symptom of technology spurts or statistical illusion? Review of World Economics, 143(2), 227 255.

25- Temouri, Y., Driffield, N. L. and Higon, D. A. (2010). The futures of offshoring FDI in high-tech sectors. Futures, 42(9), 960-970. 
26- Wu, J., Li, S. and Samsell, D. (2012). Why some countries trade more, some trade less, some trade almost nothing: the effect of the governance environment on trade flows. International Business Review, 21(2), 225-238.

27- www.worldbank.org/ wdi/gowernance: Governance Indicators Webpage.

28- www.worldbank.org. 